\title{
Chapter 11 \\ Finding Larger Transnational Media \\ Markets: Media Practices \\ of the Vietnamese Diasporic Community
}

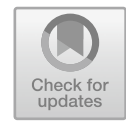

\author{
Tae-Sik Kim
}

\subsection{Introduction}

International migration involves representative practices that characterize the globalized world. While migrants' mobility has changed the everyday landscapes of our world, it has also dramatically increased the transnational communication traffic between their old and new homes. Advanced communication technologies have expanded the scope of migrants' media use, allowing them to reach various media outlets around the world. Meanwhile, they have also developed ethnic media in their own diasporic communities in global urban centers (cf. Georgiou 2017). Also, media organizations in so-called multicultural societies have set their sights on this population, making available more features representing the migrants and their presence in given societies (cf. Müller and Hermes 2010). Unlike the conventional understanding of migrants in the tradition of intercultural communication studies, which highlights a positive correlation between migrants' new cultural adaptation and their uses of a new (host) society's media, the globally mobile population has opened up a variety of media landscapes on both global and local levels.

Migrant-related media studies have focused a great deal on conventional immigrant-receiving countries, such as Anglo-American and West European countries, due to the size of their migrant communities as well as their well-developed media markets. Although recent studies have begun paying attention to the diverse media flows that have originated in previously less-studied media markets such as Brazil, Turkey and India (Thussu 2006), media studies of migrant communities in emerging multicultural societies like many Central and Eastern European countries have still been limited. This chapter is based on data from two different studies on transnational media practices in the Vietnamese diasporic community in the Czech

T.-S. Kim ( $\varangle)$

Faculty of Social Studies, Masaryk University, Jostova 10, 60200 Brno, Czech Republic e-mail: beinkid@mail.muni.cz 
Republic. As part of a larger research project on the media practices of the diasporic community, the first phase of this study involved a series of in-depth interviews with Vietnamese young adults who were competent in multiple languages, including Czech, Vietnamese and English and thus was relatively well integrated into both the Czech and Vietnamese communities. In the second phase, the study turned its focus toward Vietnamese migrants who had arrived in the CR as independent adults. These first-generation migrants were relatively confined within their diasporic community and spent more time in their workplaces. The media practices of these different types of Vietnamese migrants reflect different migration experiences. Thus, this chapter first reviews various life contexts of the different Vietnamese populations in the CR and then discusses how they have been erased from the Czech media landscape because of their adoption of transnational media practices. This study also demonstrates how the diasporic community has failed to establish a conventional form of diasporic media but instead has found new translocal information outlets on social media.

\subsection{Vietnamese in the Czech Republic}

As of 2016, 58,025 Vietnamese officially lived in the CR, composing the thirdlargest minority after Ukrainians and Slovaks (Czech Statistical Office 2017). The Vietnamese started migrating to the CR in the late 1950s when the then-Czechoslovak Government hosted workers from other communist-ally countries. There was a short period of declining numbers of Vietnamese migrant workers during the political changes around 1989, but since then, the Vietnamese diasporic community in the CR has grown dramatically (Drbohlav et al. 2009), composing the third-largest group of immigrants overall and the largest population from Asia (Kušniráková 2014). Unlike the largest single immigrant group, Ukrainians, Vietnamese migrants consist more of business owners than employees (Drbohlav and Dzúrová 2007). Reflecting the presence of Vietnamese in the Czech economy, academic studies have focused on the economic motivations for migration and labor-related issues in the CR (e.g., Huwelmeier 2015).

Although there have been multiple studies taking the Vietnamese into account in evaluating Czech immigration policies (e.g., Drbohlav and Dzúrová 2007; Trbola and Rákoczyová 2011), only a few studies have paid extensive attention to the cultural experiences of the Vietnamese in the CR (e.g., Alamgir 2013). Instead, many studies have focused on criminal activities based in the diaspora community (e.g., Drbohlav and Janská 2009; Nožina 2010; Nožina and Kraus 2016). As the migrant population has increased and become more visible, sociological studies have recently focused on the everyday practices of the Vietnamese.

A recent study shed light on the unique family experiences of Vietnamese migrants who relied on Czech nannies in their child-rearing (Souralová 2014), reflecting not only the economic condition of the migrants who worked overtime but also the demographic composition of the Vietnamese community, which consists of a relatively 
large number of children (40\%) (Kušniráková 2014). The language status of the Vietnamese in the CR is another topic investigated by multiple studies (e.g., Lin 2016; Sherman and Homolác 2017). Also, recent studies on the identity of Vietnamese migrant children demonstrated the ambivalently hovering identity of these youth in the CR (Cheng and Hu 2015; Svobodová and Janská 2016). However, much about the media practices in the Vietnamese diaspora of the CR is still unclear.

The Vietnamese have been recognized as a national minority group since 2013, along with 13 other minorities in the CR (Vláda České republiky 2018). As part of the protection of national minority cultures, the Government Council for National Minorities has financially supported multiple ethnic media projects, such as print media for the Roma community and multi-language radio programs on the public Český rozhlas (Czech Radio) covering Roma, Slovak, Polish and German communities. However, there are no specifically designed channels, programs or features in the Czech public service media for the Vietnamese community. Also, the Vietnamese have not been a target audience group in the Czech commercial media market.

Despite its relatively large size, the Vietnamese community has not founded a well-formed diasporic media presence on traditional media platforms. While there have been no diasporic outlets on electronic media platforms, a couple of Vietnameselanguage print magazines have come and gone. Viet Media, which once published two community magazines, Tuần tin mới (New Week) and Thế giới trẻ (Youth World), founded Vietinfo.eu, a Vietnamese-language Web portal, which is now managed by Vietinfo Group. Currently, An ninh thế giơi (World Security) is regularly published in the Vietnamese language. The structures of these magazines are identical. Each issue contains news on the Vietnamese community in the CR, translated news articles on Czech society and readers' opinions. However, these community-related news features are brief; the magazines consist mainly of news articles originally published by Vietnamese domestic and diasporic media outside the CR. Along with Vietinfo, Sangu.eu has penetrated into the diasporic community by serving up-todate information in the Vietnamese language. This small information outlet utilizes Facebook as the most effective communication platform, featuring a variety of types of multimedia-based information and ways of delivering it, such as live streaming. Currently, more than 25,000 Facebook users subscribe to its page, and its postings often receive more than 1000 reactions from the subscribers. Although the Vietnamese community in the $\mathrm{CR}$ has failed to establish a conventional form of diasporic media or draw attention from the Czech mainstream media, the community seems to have finally found a diasporic information outlet on the most populous new media platform.

\subsection{Media Practices in Diasporic Communities}

Global migrants have shaped a variety of transnational spaces by flexibly interacting with people across multiple borders, which is depicted by Appadurai (1990) in his notion of the five scapes of globalization. Globally, mobile people have not 
only expanded the ethnoscape by creating diasporic communities across borders but have also accelerated the shaping of the mediascape by consuming and transacting mediated information on a global scale. Gazing at the ever-changing global landscape around diasporic communities and media environments, migration and media studies have studied the transnational as well as diasporic media practices of global migrants. The sharing of information across borders helps migrants engage in domestic politics in their home countries (Aricat 2015). Media from migrants' country of origin is an important means to maintain native identity (Kama and Malka 2013). Transnational media consumption practices are also adopted by migrants as a strategy to cope with chronic cultural stresses they face in their new home (Kim 2016).

Some studies have revealed more dynamic transnational interactions over media by investigating migrants' media practices beyond the binational border between a country of origin and a receiving country. Migrants in Europe often use international news media from different countries (Christiansen 2004). Arab migrant women in the UK watch television dramas from countries other than their countries of origin (Georgiou 2012). When the Hong Kong film industry was dominant in Asia, Vietnamese migrant children in Australia became loyal consumers of Hong Kong movies available in their diasporic shops (Cunningham and Nguyen 2001). Asian migrants in the Netherlands consume non-homeland Asian media products on a regular basis, just as many Asian migrant youth in North America intensively consume Korean media products (Ju and Lee 2015; Yoon and Jin 2016). Their shared migratory experiences and cultural sensibilities have led them to transnational media products from Asian media markets not located in their countries of origin.

Global migrants have not only relied on media sources across borders but have also developed their own community media. Diasporic media have also been studied in large multiethnic societies, mainly in the Western world (Georgiou 2005; Matsaganis et al. 2010; Yu 2017). Like media from their country of origin, diasporic media often help migrants maintain ethnic identities (Yin 2015); play important roles in forming communities in new home countries (Shi 2005); and provide important information to migrants about how to make a living in a host society (Garapich 2008). However, there are only a very limited number of studies delving into migrants' transnational media use or diasporic media practices in countries with small media markets. One example is a study based in Ireland that demonstrates how multicultural news media have formed in the course of the transition to a multicultural society (Banks 2008). As Jõesaar et al. (2013) rightly noted in their study of Russian-language media in the small Estonian media market, the population of minorities in a small-media-market society tends to be tiny, so it draws little attention not only from domestic media organizations but also within academic circles.

\subsection{Contextualizing Vietnamese Populations in the CR}

As noted above, initial studies regarding Vietnamese migrant children in the CR were conducted in recent years. In the first study, the population investigated generally 
shared multiple demographic characteristics, like a relatively stable socioeconomic status, higher human capital and integration into both diasporic and Czech communities. During the interviews, participants often differentiated themselves from their parents' generation mainly by their multilingualism, Czech cultural literacy and global lifestyles. The children of migrants also drew a line between themselves and other young Vietnamese migrants who recently migrated to the CR on their own. They limited their interaction with the newcomers mainly because the two populations did not share many life experiences and living spaces in the CR.

Most of the first generation of Vietnamese arrived in the 1990s. Their migration trajectories are difficult to generalize; it was more common for the head of a household to come first to the CR to pave the way for his or her family to settle in the new country. They often travelled back and forth between Vietnam and the CR to bring necessary resources and family members. Most adult migrants spent a tremendous amount of time at their workplaces in order to support their families. It is now 2030 years since their migration, and they have a reputation as hardworking migrants who have succeeded relatively well in their economic life. The Vietnamese diasporic community formed a large Vietnamese business complex called Sapa on the outskirts of Prague and established similar wholesale businesses in other cities like Brno. Backed by the huge wholesale network within the diasporic community, many Vietnamese are known as owners of small to midsized shops. It is common to see a small grocery store, called potraviny or večerka, owned by a Vietnamese merchant on every street corner. Also, many Vietnamese vendors are active in a number of border towns adjacent to Germany, Austria and Poland. While they have built exclusively Vietnamese wholesale complexes and business networks within the diaspora, their residences are quite spread out. For example, there are no specific Vietnamese residential communities in the major cities like Prague and Brno. In other words, the first generation of Vietnamese managed their community integration strategy by, on the one hand, going deep into the everyday spaces of Czech people and, on the other hand, by maintaining an exclusive "ethnic enclave economy" (Werbner 2001). Nevertheless, the economic migrants spend most of their working time either in their shops or in other Vietnamese businesses like those in Sapa. Many who maintained this work pattern from the early days of their migration neither improved their Czech language skills nor built a healthy social network with Czech people. According to a criterion from conventional acculturation studies, they are a population quite separated from mainstream Czech society (Berry 1997). By and large, these middle-aged migrants who have lived in the CR for more than 20 years do not have a particular plan to go back to Vietnam, although many of them initially dreamed of eventually returning to their home country after making money in the CR.

In contrast, young adult migrants, who are often called the 1.5 generation, tend to be visible in both the Vietnamese community and Czech society. These young Vietnamese came to the CR at a young age (mostly between three and ten years old),

\footnotetext{
${ }^{1}$ There have been controversies over the concept of an ethnic enclave economy. The concept used in this paper is grounded in Werbner's (2001) definition of ethnic enclave economy as ethnically networked businesses that generate ethnic social space by transacting particular goods and services.
} 
following their parents. These young adults generally shared similar life experiences in their early years in the CR; their parents worked long hours at factories, grocery stores or other Vietnamese-owned businesses; they were mostly cared for by Czech nannies or their grandparents; and they spent most of their weekday daytime hours at Czech educational institutions. For many of them, the Czech language is their first language due to these childhood experiences. However, they have also been pushed to speak Vietnamese at home by their parents, who have prioritized Vietnamese family values in their children's upbringing and discipline. Although many of their parents still work almost every day, the migrant children have spent relatively long hours with their parents since their economic condition has stabilized. As grownups, they also participate in economic activities. While some of them assist their parents in their own shops, others also work outside the diasporic community. Their multilingual skills are attractive to both Vietnamese and Czech businesses located in urban centers, which have benefited from the recent boom in tourism and rapid globalization. In our interviews, the young adults often used the term banana ${ }^{2}$ as a means of characterizing their different identities. Participants in this study commonly identified themselves as "less banana" than their younger siblings, who were mostly born in the CR. Thus, our respondents placed themselves between the first generation and the second generation, which is the reason they are often called the " 1.5 generation." Generally cosmopolitan in nature, they have travelled to many different countries, including Vietnam, thanks to their family's economic prosperity and various educational opportunities available in European Union Member States. However, most of them want to live in the CR or other states in Europe permanently instead of in Vietnam.

Another group of young adults in the Vietnamese community consists of recent migrants who came to the CR on their own. They generally share similar migration trajectories not with the 1.5 generation within the same age range but with the older and earlier first generation. The majority of the new migrants work at businesses owned by other Vietnamese. They are more visible in Vietnamese business complexes like Sapa than in Czech urban centers, mainly due to enclave economic practices. Thus, they rely almost exclusively on various networks within the diasporic community. It is known that they often form intimate communities with those who share the same migratory experiences in order to exchange emotional support as well as daily information. Not unlike the earlier generation of migrants, their limited language skills hinder them from seeking alternatives in Czech society. Since the opportunity and support for language acquisition are limited in the community, some of them take language courses at their own expense. The cost of private lessons, along with a shortage of time due to working long hours, prevents them from acquiring the Czech language successfully. Also, very few of them speak other European languages, which leave them few options for jobs outside the diasporic community.

\footnotetext{
2"Banana" is a widely used slur referring to Asian migrant children in a Western country, who identify themselves more with their new western home culture than with their Asian home culture.
} 
Their future plans vary; while some of them plan to stay in the CR permanently, some define themselves as temporary economic migrants, and others are more flexible and are open to every possibility.

\subsection{Crossing the Binational Border: Media Practices of the Early First Generation}

In Vietnamese wholesale complexes like Sapa and on Olomoucká Street in Brno, it is very common to see owners and clerks in the shops watching television in the Vietnamese language. During downtime at a small shop or potraviny, one may hear Vietnamese sound emanating from a tiny screen under the counter. During the interviews, migrant children often said that Vietnamese satellite television programs worked like background music during their family mealtimes because their parents were tuned in to these channels. Such scenes characterize quite well the media practices of the first generation of Vietnamese migrants in the CR. Busy small-business owners are heavy, yet mindless, users of Vietnamese satellite television. For those who have a low competence in languages other than their mother tongue, the media from their country of origin seems to be the sole option. Although they are gradually moving from old electronic media to online social media as their main information outlet, they still spend a large amount of time with Vietnamese satellite television, mainly due to their working environments.

For those who are not very adept in exploring alternative sources of information on different media platforms like the Internet, satellite television is the most affordable as well as the most reliable media outlet. Satellite television has long been the basic, primary medium for the early migrants, who were not able to use any media based in the CR due to the language barrier. Even if some of our participants once used video players like VCRs, VCDs and DVDs to watch media products from Vietnam, they had only limited time to enjoy them. Instead, they have relied more on Vietnamese satellite channels available from both Czech Television providers and Vietnamese diasporic businesses. Although they have Internet-connected computers and smartphones at their places of work as well as at home, most still subscribe to Vietnamese satellite television at both places, mainly due to their routinized media use. Watching —or just turning on-Vietnamese television is not only an individual media practice but also a diaspora practice. Maintaining close business networks, Vietnamese often visit each other's workplaces, such as restaurants, wholesale shops and hair-and-nail shops, where the same satellite television is usually turned on.

Habitually and constantly exposed to television programs from Vietnam, the early migrants tend not to look for alternative sources. Many of those who once tried to adopt Czech media failed to become regular users, mainly due to the lack of programs that suit their interests. They have failed to find interesting programs on Czech network television, but they have also not been attracted to Czech cable channels, which are full of imported media products. The Czech-dubbed American and British 
media products barely entertain the early migrants, who are not comfortable with the Czech language. Rather, they are content with Vietnamese satellite television and media products with Vietnamese subtitles, which are available on the Internet.

Working in an enclave economic community, the early migrants very often obtain useful daily information from the community. Word of mouth is one of the most important information sources for those who maintain their exclusive, diasporic business networks. Vietnamese-language magazines have been published for many years, but most of them have failed to take hold in the community. Published by a few media agencies covering multiple Vietnamese communities across Europe, magazines commonly consist of news from Vietnam and other Vietnamese overseas communities, Czech domestic news relevant to the diasporic community and general news from all over the world. In other words, these magazines spend only the first few pages covering information directly associated with the community in the CR. Also, these magazines are not distributed in a systematic way but instead are displayed at stores with other commercial flyers. Many early migrants once attempted to skim some editions; but in their interviews, they did not recall well the titles of magazines and specific types of information. Generally, few respondents said that there has been a proper form of journalism in their community.

While still relying heavily on word of mouth as the primary source of information, the early migrants have recently adopted online information outlets such as Vietinfo.eu and Sangu.eu. Whereas Vietinfo.eu is an online form of the abovementioned Vietnamese-language magazines, Sangu.eu is an online blog-style community magazine that provides multimedia-based information specifically relevant to the diaspora community. Many participants who have been active on Facebook in recent years (mostly for the last two to three years) subscribe to the Facebook pages of both services. In addition, non-users of Czech media outlets often come across news and information produced by Czech media on social media. Technologically assisted translation services and social sharing features on social media finally allow them to make use of Czech news and information outlets. Having long lacked participation in the small Czech media market, the early migrants have gradually become at least passive audiences of Czech media.

\subsection{Crossing the Binational Border Online: Media Practices of the Recent First Generation}

As explained above, the early first generation and the recent first generation of Vietnamese migrants generally share two important life contexts: They have low competence in Czech and other foreign languages, and they are quite confined within the Vietnamese diaspora community. However, the two populations deviate from each other when it comes to media use. Working long hours at Vietnamese businesses, the young recent migrants are also ordinarily exposed to Vietnamese satellite television. As it was for the early first generation, Vietnamese satellite television 
has been contextualized in their work life since the beginning of their life in the CR. Unlike their predecessors, however, the relatively young migrants tend not to subscribe to the satellite service on their own. Like young people in general, they intensively use online media available on both their personal computers and mobile devices. For them, watching television means consuming television content available online. In fact, most of them adopted online media during their early years in Vietnam. They also access various transnational media products, such as Asian television shows and sports events including European football leagues and mixed-martial-arts matches, via Vietnamese Web sites. Even though they frequently use YouTube and other global media platforms to watch live streaming and video clips that interest them, it is online information in the Vietnamese language that mainly links them to these global channels.

The younger migrants prioritize connectivity in their lives, willingly spending their money on mobile data and high-speed Internet services. They rely on online social networks to obtain essential information for living in their new home. Their online social networks on Facebook, Instagram and messaging applications provide not only essential practical information on the economy, education and health but also cultural information to entertain them. They have built online diasporic communities by maintaining exclusive social networks with compatriots both in Vietnam and in the CR. Even though they currently live in the CR, they still receive information and various kinds of support from the network in Vietnam by using online communication tools. Also, online social networks allow them to continue to be involved in the initial human networks they first formed after arriving in the CR. For recent migrants, the online social network has not been one of many optional information outlets. Instead, they have shaped their migrant life by using the online social network to exchange information within the diasporic and the transnational Vietnamese communities.

\subsection{Crossing Multiple Borders: Transnational Media Practices of the 1.5 Generation}

Born in Vietnam and raised in the CR, the migrant children who have benefited from their family's economic stability and diverse educational opportunities in both the Czech and Vietnamese communities have expanded the scope of their transnational media practices. Their multilingual skills have allowed them to reach various media outlets ranging from Czech and Vietnamese to Western and Asian media. The 1.5 generation used to watch Czech Television shows for children and video products and satellite television from Vietnam with their parents and siblings. However, these binational media practices did not last very long. Most of them stopped watching Czech Television and Vietnamese satellite television after adopting private media practices with their personal devices such as laptops and mobile phones. As young digital natives, they have long been online users who adroitly surf new media services from all around the world. As residents in rapidly globalizing urban areas, they 
have nurtured cosmopolitan cultural tastes, preferring well-developed media products from the USA, the UK, Japan and South Korea (hereafter Korea). They have turned their backs on Czech and Vietnamese media partly because of the outdated styles of those media products and partly because of the lack of variety. In other words, young cosmopolitan audiences are no longer confined within the two small media markets of the CR and Vietnam because they make use of various media outlets from bigger transnational media markets.

While heavily using transnational online streaming services such as YouTube and Netflix, they also consume Korean media products intensively. It is known that there is a large fandom for K-pop music and Korean television shows in the Vietnamese community of the CR. These young transnational media fans first learned about Korean cultural products from media based in Vietnam, as well as from their family members and Vietnamese friends in the CR. The Korean media industry has been dominant in many Southeast Asian countries, including Vietnam, since the late 1990s (Peichi 2013). The cultural phenomenon has crossed borders by following the migratory trajectory of the Vietnamese overseas. Once introduced to Korean media by Vietnamese media and human networks, the migrant young adults have explored more readily available media sources by using their language skills and available technology; they watch Korean television shows and K-pop music products uploaded by users across the world on streaming services from different countries including China, Turkey, the USA and Vietnam; they consume information about the Korean entertainment industry by surfing around various Web sites and subscribing to relevant social media pages. Despite the increasing number of Korean media fans in the CR, the Czech market is still out of the Korean media's target range. Also, Korean television shows available on Netflix in the CR are much more limited than those accessible in bigger media markets, such as the USA and Japan, due to licensing issues. For this reason, many Vietnamese audiences in the CR rely heavily on illegally uploaded content on various streaming services across the world. Fans often volunteer to introduce Korean media culture and trends to their Czech peers, which is slowly generating a niche market in the CR. Following the global trend, the young Vietnamese have recently become loyal users of YouTube and Netflix, where the national origin of media products is underplayed. They often watch media products from many different countries on their streaming services. Together with Czech consumers of streaming services, the 1.5 generation has pushed the boundary of the Czech media market.

As residents of the CR, they also use the most-visited Czech Web portal, Seznam.cz, to find daily information on a regular basis. Many use the portal's e-mail service, compare prices of e-commerce products and check the news headlines on the front page of the Web site. They also spend a large amount of time on social media, where they practice more personalized information-seeking modalities. The blurring territories of online media make it difficult to simply state where 1.5 generation users are based; while being active subscribers to diasporic Facebook pages in the Czech language, such as "Přiznání Vietnamců" ("Recognition of Vietnamese") and "Viet Up," they are also involved in a variety of online networks with Czechs and people from around the world. Although they do not regularly consume Czech news media, they subscribe to the Facebook feeds of Czech news organizations. Old print media 
distributed in the Vietnamese community and Vietnamese news via satellite television are not taken into consideration as useful news outlets by the young migrants, but online diasporic information outlets such as Sangu.eu are well recognized by them. They are not different from other social media users who cross national and regional borders without noticing their own extensive mobilities online. The migrant children who once turned their backs on the limited media markets in the CR and their diasporic community have formed dynamic information outlets on deterritorialized social media.

\subsection{Conclusion}

During a couple of interviews with the old and new first generations, interviewees who knew I was originally from Korea asked me a question: "Do you know Park Hang Seo?" Of course, I know the name because the Korean football coach has become a celebrity in Korea with his achievements in Vietnam. He is the head coach of the Vietnamese national football team, which has achieved remarkable results in several inter-Asian football events. Because I was conducting open-ended interviews, I could ask the interviewees more about their media practices related to the Vietnamese national football team. They said they did their best to watch live coverage of matches while keeping informed about the team by accessing various information outlets across the border. They have, for example, subscribed to related Facebook pages and visited Vietnamese news sites more often than before. Some respondents recently bought a more extensive satellite television box from Vietnam, which covers all television channels in Vietnam. National events across the border and advanced border-crossing technologies have helped the diasporic migrants feel more synchronized with daily life in their country of origin. Likewise, transnational media practices are deeply contextualized in global migrants' lives. Moreover, the practices are neither static nor patterned but are instead continuously evolving as the migrants respond to various sociocultural changes in their countries of origin, their new home countries and their own diasporic communities, and beyond.

This chapter has reviewed how different Vietnamese migrant populations in the CR have shaped their transnational and community media practices. Those who are quite separated from mainstream Czech society have made almost no use of the Czech media market. The small Czech media market has not taken the tiny Vietnamese population into consideration as a target audience. In addition, the diasporic community has not been successful in forming its own media outlets due to the limited efforts of its business-oriented community. On the other hand, the well-educated and globalized younger generation has not been satisfied with the limited Czech, Vietnamese and diasporic media landscape. Equipped with technologies and cosmopolitan skills, the young migrants have explored the transnational, global media space. It is obvious that the Vietnamese diasporic community in CR is not premature in forming a media market comparable with those in larger multiethnic countries like the USA 
and Canada. It is also obvious that a small media market facing ever-increasing competition with larger transnational media markets cannot afford to cater to a small diasporic community accounting for less than $1 \%$ of the entire population. Thus, neglected diasporic audiences in small media markets seem to create a tautological dilemma.

As seen above, however, the Vietnamese migrants adopting networked media platforms like Facebook have opened up their own translocal media outlets. Advanced technological features help them to overcome such barriers as the lack of language skills and limited prerequisite knowledge. The migrant social media users often come across information outlets based on the CR. Meanwhile, they have expanded the scope of their use of Vietnamese and other transnational media outlets even further by surfing links shared on social media. In sum, the " 1.5 generation" migrants are staying far away from conventional Czech and diasporic media while simultaneously finding transnationally networked Czech media outlets and Vietnamese diasporic information outlets on social media.

Because it is grounded in a limited number of interviews with Vietnamese migrants, this research needs to be further developed to cover more diverse populations in the community. Further study is expected to shed more light on the role of new media platforms in shaping transnational-translocal media practices in a diasporic community.

\section{References}

Alamgir, A. K. (2013). Race is elsewhere: State-socialist ideology and the racialisation of Vietnamese workers in Czechoslovakia. Race \& Class, 54(4), 67-85.

Appadurai, A. (1990). Disjuncture and difference in the global cultural economy. Theory, Culture \& Society, 7(2-3), 295-310.

Aricat, R. G. (2015). Mobile/social media use for political purposes among migrant laborers in Singapore. Journal of Information Technology and Politics, 12(1), 18-36.

Banks, M. (2008). Modern Ireland: Multinationals and multiculturalism. Information, Society and Justice Journal, 2(1), 63-93.

Berry, J. W. (1997). Immigration, acculturation, and adaptation. Applied Psychology, 46(1), 5-34.

Cheng, T.-H., \& Hu, L.-Y. (2015). The dual identity and social integration of international immigrants in the Czech Republic: A survey research on the second generation of Chinese and Vietnamese immigrants. Tamkang Journal of International Affairs, 19(1), 129-197.

Christiansen, C. C. (2004). News media consumption among immigrants in Europe: The relevance of diaspora. Ethnicities, 4(2), 185-207.

Cunningham, S., \& Nguyen, T. (2001). Popular media of Vietnamese diaspora. In S. Cunningham \& J. Sinclair (Eds.), Floating lives: The media and Asian diasporas (pp. 91-135). New York: Rowman and Littlefield.

Czech Statistical Office. (2017). Foreigners in the Czech Republic. Czech Statistical Office. https://www.czso.cz/documents/10180/45709982/29002717.pdf/770a1c14-6ea7-4c47-831e3936e3ca1ab3?version=1.2. Accessed September 18, 2018.

Drbohlav, D., \& Dzúrová, D. (2007). Where are they going? Immigrant inclusion in the Czech Republic (A case study on Ukrainians, Vietnamese, and Armenians in Prague). International Migration, 45(2), 69-95. 
Drbohlav, D., \& Janská, E. (2009). Illegal economic and transit migration in the Czech Republic: A study of individual migrants' behaviour. Europe-Asia Studies, 61(1), 141-156.

Drbohlav, D., Lachmanová-Medová, L., Čermák, Z., Janská, E., Čermáková, D., \& Dzúrová, D. (2009). The Czech Republic: On its way from emigration to immigration country. IDEA Working Papers 11. https://is.muni.cz/el/1423/jaro2004/SOC732/um/Drbohlav_et.al._2009._The_ Czech_Republic.On_its_way_from_emigration_to_immigration_country.pdf. Accessed December $15,2018$.

Garapich, M. P. (2008). The migration industry and civil society: Polish immigrants in the United Kingdom before and after EU enlargement. Journal of Ethnic and Migration Studies, 34(5), $735-752$.

Georgiou, M. (2005). Diasporic media across Europe: Multicultural societies and the universalismparticularism continuum. Journal of Ethnic and Migration Studies, 31(3), 481-498.

Georgiou, M. (2012). Watching soap opera in the diaspora: Cultural proximity or critical proximity? Ethnic and Racial Studies, 35(5), 868-887.

Georgiou, M. (2017). Mapping diasporic media cultures: A transnational cultural approach to exclusion. In R. Silverstone (Ed.), Media, technology and everyday life in Europe (pp. 51-70). London: Routledge.

Huwelmeier, G. (2015). From 'Jarmark Europa' to 'commodity city'. New marketplaces, postsocialist migrations, and cultural diversity in Central and Eastern Europe. Central and Eastern European Migration Review, 4(1), 27-39.

Jõesaar, A., Jufereva, M., \& Rannu, S. (2013). Media for the minorities: Russian language media in Estonia 1990-2012. Media Transformations, 9, 118-154.

Ju, H., \& Lee, S. (2015). The Korean wave and Asian Americans: The ethnic meanings of transnational Korean pop culture in the USA. Continuum, 29(3), 323-338.

Kama, A., \& Malka, V. (2013). Identity prosthesis: Roles of homeland media in sustaining native identity. Howard Journal of Communications, 24(4), 370-388.

Kim, T.-S. (2016). Transnational communication practices of unaccompanied Young Korean students in the United States. Asian and Pacific Migration Journal, 25(2), 148-167.

Kušniráková, T. (2014). Vietnamci v Česku a ve světě: Migrační a adaptační tendence [Vietnamese in the Czech Republic and in the world: Migratory and adaptive tendencies]. Praha: Slon.

Lin, M. S. (2016). Limits of the EU language education policy for migrants: A comparative study of the Vietnamese migrant community in the Czech Republic and the new immigrants in Taiwan. Sustainable Multilingualism, 9, 78-101.

Matsaganis, M. D., Katz, V. S., \& Ball-Rokeach, S. J. (2010). Understanding ethnic media: Producers, consumers, and societies. Thousand Oaks, CA: Sage.

Müller, F., \& Hermes, J. (2010). The performance of cultural citizenship: Audiences and the politics of multicultural television drama. Critical Studies in Media Communication, 27(2), 193-208.

Nožina, M. (2010). Crime networks in Vietnamese diasporas: The Czech Republic case. Crime, Law and Social Change, 53(3), 229-258.

Nožina, M., \& Kraus, F. (2016). Bosses, soldiers and rice grains: Vietnamese criminal networks and criminal activities in the Czech Republic. Europe-Asia Studies, 68(3), 508-528.

Peichi, C. (2013). Co-creating Korean wave in Southeast Asia: Digital convergence and Asia's media regionalization. Journal of Creative Communications, 8(2-3), 193-208.

Sherman, T., \& Homoláč, J. (2017). 'The Older I Got, It Wasn’t a Problem for Me Anymore': Language brokering as a managed activity and a narrated experience among Young Vietnamese immigrants in the Czech Republic. Multilingua, 36(1), 1-29.

Shi, Yy. (2005). Identity construction of the Chinese diaspora, ethnic media use, community formation, and the possibility of social activism. Continuum, 19(1), 55-72.

Souralová, A. (2014). The Czech Nanny as a "Door to Majority" for children of Vietnamese immigrants in the Czech Republic. Studia Migracyjne-Przeglad Polonijny, 3(40), 171-186.

Svobodová, A., \& Janská, E. (2016). Identity development among youth of Vietnamese descent in the Czech Republic. In M. L. Seeberg \& E. Gozdziak (Eds.), Contested childhoods: Growing up in migrancy (pp. 121-137). Berlin: Springer. 
Thussu, D. K. (2006). Media on the move: Global flow and contra-flow . London: Routledge.

Trbola, R., \& Rákoczyová, M. (2011). Barriers to integration of immigrants and integration policy in the Czech Republic with focus on stakeholders and their co-operation. Migracijske i etni ${ }^{`}$ cke teme, 27(1), 77-104.

Vláda České republiky. (2018). Rada vlády pro národnostní menšiny [Government council of national minority]. https://www.vlada.cz/en/pracovni-a-poradni-organy-vlady/rnm/historie-asoucasnost-rady-en-16666/. Accessed December 15, 2018.

Werbner, P. (2001). Metaphors of spatiality and networks in the plural city: A critique of the ethnic Enclave economy debate. Sociology, 35(3), 671-693.

Yin, H. (2015). Chinese-language cyberspace, homeland media and ethnic media: A contested space for being Chinese. New Media \& Society, 17(4), 556-572.

Yoon, K., \& Jin, D. Y. (2016). The Korean wave phenomenon in Asian diasporas in Canada. Journal of Intercultural Studies, 37(1), 69-83.

Yu, S. S. (2017). Ethnic media as communities of practice: The cultural and institutional identities. Journalism, 18(10), 1309-1326.

Tae-Sik Kim is Assistant Professor at the Department of Media Studies and Journalism, Masaryk University, Brno, Czech Republic. His research concerns transnational communication, migrant studies, urban community and communication, media technologies and cultural citizenship. Grounded in anthropological concerns, he is currently working on multiple research projects ranging from the Vietnamese in the Czech Republic to the Chinese in South Korea.

Open Access This chapter is licensed under the terms of the Creative Commons Attribution 4.0 International License (http://creativecommons.org/licenses/by/4.0/), which permits use, sharing, adaptation, distribution and reproduction in any medium or format, as long as you give appropriate credit to the original author(s) and the source, provide a link to the Creative Commons license and indicate if changes were made.

The images or other third party material in this chapter are included in the chapter's Creative Commons license, unless indicated otherwise in a credit line to the material. If material is not included in the chapter's Creative Commons license and your intended use is not permitted by statutory regulation or exceeds the permitted use, you will need to obtain permission directly from the copyright holder.

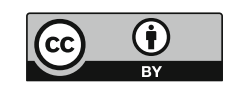

